\title{
МЕНЕДЖМЕНТ
}

UDC 658:330.131.7(657)

S. F. Lehenchuk, Doctor of Economics, Professor,

I. M. Vygivska, Candidate of Economic Sciences, Associate Professor, T. P. Barchak, Postgraduate

\section{INFORMATION SUPPORT ISSUES OF RISK MANAGEMENT OF SOCIALLY RESPONSIBLE CORPORATIONS}

Urgency of the research. In today's economic environment uncertainty and risk overwhelm any business. $A$ large number of risks are inherent in socially responsible business, which necessitates the need for enhanced monitoring and management, the effectiveness of the risk management system and requires finding new directions for its development.

Target setting. Satisfaction of stakeholders' information interests necessitates research of the current state of the risk management system of large companies, their standardization, disclosure of risks in the reporting of socially responsible business.

Actual scientific researches and issues analysis. The research of problematic issues regarding risk management of the activity of economic entities was carried out by such scientists as A. P. Algin, P. Y. Atamas, I. T. Balabanov, I. A. Blank, V. V. Vitlinskyy, L. V. Hnylytska, B. A. Zasadnyi, A. B. Kaminsky, T. M. Korolyuk, G. V. Savitska, A. E. Shevelev, O. V. Sheveleva, A. D. Sheremet, O. I. Yastremskii.

Uninvestigated parts of general matters defining. Comprehensive research requires the standardization of risk management as well as the creation of an information resource on risk management of socially responsible business for stakeholders.

The research objective. Analysis of the annual reports of socially responsible companies (on the example of enterprises of agro-industrial complex) will enable to identify the risks inherent in their activities, methods of managing them as well as to establish the extent to which the issue of quantifying the negative effects of risks and opportunities can be identified.

The statement of basic materials. This article analyzes the state and trends of risk management development of socially responsible business, establishes an insufficient level of presenting information on risk in the reporting of agribusiness companies and low degree of communicating information to stakeholders on quantifying the impact of risks and opportunities.

Conclusions. Suggestions to increase the effectiveness of the risk management system of socially responsible companies through international risk management certification are made. The directions of development of the risk management system in terms of quantitative measurement of the consequences of risks and opportunities with the purpose of meeting the information needs of stakeholders have been identified.

Keywords: management; risk; social responsibility; corporations; management report.
УДК 658:330.131.7(657)

С. Ф. Легенчук, д. е. н., профресор,

І. М. Вигівська, к. е. н., доцент,

Т. П. Барчак, аспірант

\section{ПРОБЛЕМИ ІНФОРМАЦІЙНОГО ЗАБЕЗПЕЧННЯ УПРАВЛІННЯ РИЗИКАМИ СОЦІАЛЬНО ВІДПОВІДАЛЬНИХ КОРПОРАЦІЙ}

Актуальність теми дослідження. у сучасних умовах господарювання невизначеність та ризики переповнюють діяльність будь-якої компанії. Соціально відповідальному бізнесу притаманна значна кількість ризиків, що зумовлює необхідність посиленого моніторингу та управління ними, ефективність системи ризик-менеджменту та вимагає пошуку нових напрямів його розвитку.

Постановка проблеми. Задоволення інформаційних інтересів стейкхолдерів зумовлюе необхідність дослідження питання сучасного стану системи ризикменеджменту великих компаній, їх стандартизації, розкриття інформації про ризики у звітності соціально відповідального бізнесу.

Аналіз останніх досліджень $і$ публікацій. Дослідженням проблемних питань щодо управління ризиками діяльності суб'єктів господарювання у своїх працях займалися такі вчені як: А. П. Альгін, П. Й. Атамас, I. T. Балабанов, I. А. Бланк, В. В. Вітлінський, Л. В. Гнилицька, Б. А. Засадний, А. Б. Камінський, T. М. Королюк, Г. В. Савицька, А. Є. Шевелев, О. В. Шевелева, А. Д. Шеремет, О. І. Ястремський.

Виділення недосліджених частин загальної проблеми. Комплексного дослідження вимагає питання стандартизації ризик-менеджменту та створення інформаційного ресурсу про управління ризиками соціально відповідального бізнесу для стейкхолдерів.

Постановка завдання. Аналіз річних звітів соціально відповідальних компаній (на прикладі підприємств агропромислового комплексу) дозволить ідентифрікувати ризики, які притаманні їх діяльності, методики управління ними та встановити ступінь розкриття питання кількісного вимірювання негативних наслідків ризиків та можливостей.

Виклад основного матеріалу. У цій статmі проаналізовано стан та тенденції розвитку ризикменеджменту соціально відповідального бізнесу, встановлено недостатній рівень представлення інформації про ризики у звітності компаній АПК та низький ступінь доведення інформації до стейкхолдерів про кількісну оцінку наслідків ризиків та можливості.

Висновки. Надано пропозиції щодо підвищення ефрективності системи ризик-менеджменту соціально відповідальних компаній через міжнародну сертифікацію управління ризиками. Виявлено напрями розвитку системи ризик-менеджменту в частині кількісного вимірювання наслідків ризиків та можливостей з метою задоволення інформаційних потреб стейкхолдерів.

Ключові слова: управління; ризик; соціальна відповідальність; корпорації; звіт про управління. 


\section{МЕНЕДЖМЕНТ}

DOI: 10.25140/2410-9576-2020-2-1(20)-92-103

Urgency of the research. Any business activity is aimed at making a profit, but making a profit is not the ultimate goal of a socially responsible business. Businesses are aware of the importance of having a positive impact on their country, region and city, as well as creating favorable conditions for improving the well-being of society, ending negative demographic processes and environmental disasters. Considering that a significant amount of risks are inherent in a socially responsible business, there is a need for enhanced monitoring and risk management of the company's activities and finding directions for development and improving the efficiency of the risk management system.

Target setting. Imperfection and inconsistency of risk management of companies, as well as the contradiction of the risk management system with the modern needs of stakeholders lead to the problem of completeness and significance of disclosure of aspects of socially responsible business in conditions of risk and uncertainty, on the decision of which our research is directed.

Actual scientific researches and issues analysis. The research of problematic issues regarding risk management of the activity of economic entities was carried out by such scientists as A. P. Algin, P. Y. Atamas, I. T. Balabanov, I. A. Blank, V. V. Vitlinskyy, L. V. Hnylytska, B. A. Zasadnyi, A. B. Kaminsky, T. M. Korolyuk, G. V. Savitska, A. E. Shevelev, O. V. Sheveleva, A. D. Sheremet, O. I. Yastremskii. However, the problem of the effectiveness of the risk management system and the results of its operation in providing stakeholders with information about risks, their consequences and management actions remains urgently insufficiently studied.

The purpose of the article is to analyze the annual reports of socially responsible companies (on the example of agro-industrial enterprises), which will identify the risks inherent in their activities, methods of managing them and establish the degree of quantitative measurement of negative consequences of risks and opportunities.

The statement of basic materials. To reduce or avoid the negative impact of risks and related other phenomena and processes, it is necessary to implement measures and procedures of the risk management system that allow to effectively manage the risks of companies and minimize threats to the entity. If analyze the enterprises engaged in business activities for the production and/or sale of certain goods, it is possible to summarize the risks of such entities into several groups that affect the main processes of economic activity: purchase of raw materials, production of finished products and its sale. Such enterprises have well-known risks that can be avoided by implementing the necessary control and management measures.

The entrepreneurial risk is understood as the probability (threat) of loss of part of its resources, to receive less of income, the occurrence of additional costs as a result of activities.

Entrepreneurial risks (for an entity that is a for-profit organization) should be allocated to the following activities: 1) risks of operational activity: 1.1) risks of the supply process (purchase risk, transport, leasing, currency, legal); 1.2) production risks (venture, technical, environmental, innovation and technological); 1.3) risks of the sales process (commodity, commercial, transport, legal, trade, currency, marketing, insolvency risk); 2) risks of financial activity (credit, inflation, currency, interest rate and deposit risks, risk of insolvency and disturbance of financial balance and development, etc.); 3) risks of investment activity include risks: 3.1) real investment (capital risk, portfolio risk and building); 3.2) financial investment (risk of reduced profitability, portfolio risk, etc.).

Given the uncertainty of the economic conditions of large companies (corporations), they are characterized by high risk in all areas and aspects of activity. At the same time, in the successful case, they are guaranteed great benefits, including huge profits. Taking into account the fact that large companies in accordance with their structure and purpose are specific entities, this raises the mandatory question of implementing and regulating the risk management system, considering the peculiarities of the operation of such companies in the market.

Summarizing and refining the above, we can identify the following main risks inherent in corporations (Tab. 1). According to Table 1 the risks may not always have a negative impact on economic activity. In order to improve the company's systems and processes, it is necessary to implement measures to identify risks in a timely manner, which will help to make an effective risk 


\section{МЕНЕДЖМЕНТ}

management system in the enterprise. If analyze all threats in time and determine the possibility of their occurrence, it is possible to reduce the cost of eliminating the negative consequences and phenomena, which provides a kind of security in certain aspects of activities, i.e. protects against unforeseen factors, external influences and third parties.

Therefore, let's consider in more detail the essence and importance of implementing a risk management system in the management of companies.

Lytjuga Ju. V. defines risk management as "aimed at finding the optimal balance between the high level of risk, that can lead to the collapse of the enterprise, and the complete abandonment of it, which leads to loss of competitiveness" [1].

Risk management means the implementation of the company's development objectives. A significant part of the necessary information support for risk management is provided by the accounting system [3].

Table 1

The main risk groups of socially responsible business and their impact on business processes and company systems

\begin{tabular}{|c|c|c|}
\hline № & Risk & $\begin{array}{c}\text { Entities, processes and systems that are associated with risk or are most exposed to } \\
\text { threats }\end{array}$ \\
\hline 1 & 2 & 3 \\
\hline 1 & $\begin{array}{l}\text { Lots of small } \\
\text { threats and } \\
\text { uncertainties }\end{array}$ & $\begin{array}{l}\text { All groups of subjects, processes and systems of the company. Minor issues are not taken } \\
\text { into account in time. Problem solving occurs in each individual case when the situation } \\
\text { becomes critical. Influence consists in disclosure of unresolved issues, tasks, missed anc } \\
\text { not taken into account aspects of activity, not detected in time crisis phenomena and other } \\
\text { negative management processes }\end{array}$ \\
\hline 2 & $\begin{array}{l}\text { Problems with } \\
\text { intellectual } \\
\text { property rights }\end{array}$ & $\begin{array}{l}\text { Subjects: owner, government agencies, competitors. Systems: accounting, control } \\
\text { management. All processes of economic activity. The presence of permits and registration } \\
\text { documents to conduct activities with own developments reduces the likelihood of theft o } \\
\text { intellectual property products. Patents and other documents, as well as intangible assets } \\
\text { must be reflected in the accounting system and be evidence in disagreements and } \\
\text { lawsuits }\end{array}$ \\
\hline 3 & $\begin{array}{l}\text { Lack of proper } \\
\text { funding }\end{array}$ & $\begin{array}{l}\text { ects: founders, investors, financial institutions, government agencies. Systems } \\
\text { bunting, analysis, control, planning, management. The threat of non-receipt ol } \\
\text { erreception of investments, financing directly affects the company's entry into the } \\
\text { ket and its further operation and development }\end{array}$ \\
\hline 4 & $\begin{array}{ll}\text { oility of } \\
\text { turn }\end{array}$ & $\begin{array}{l}\text { utions. Systems - planning, analysis } \\
\text { erials, production, calculations and other } \\
\text { or underreception of investments }\end{array}$ \\
\hline 5 & $\begin{array}{l}\text { Low profitability } \\
\text { and the } \\
\text { possibility of } \\
\text { losing profits }\end{array}$ & $\begin{array}{l}\text { accounting, analysis, control, planning, budgeting, } m \\
\text { equipment, development of innovative products, } t \\
\text { inconsistency of the actual financial and economic } \\
\text { negative sentiments of the owners and other internal } \\
\text { may lead to a loss of investors. Influences the } \\
\text { company, its economic, technological, innovative, }\end{array}$ \\
\hline 6 & $k$ of highly & $\begin{array}{l}\text { ns - accounting, analysis, control, planning } \\
\text { production, sales. The threat of improving }\end{array}$ \\
\hline t & $\begin{array}{l}\text { Fulfillment of } \\
\text { obligations by } \\
\text { counterparties }\end{array}$ & $\begin{array}{l}\text { cts - founders, investors, financial institutions. Systems - accounting, analysis } \\
\text { ol, planning, budgeting, management. Processes - purchase of raw materials } \\
\text { uction, calculations and other current operating activities. The threat of non-receipt ol } \\
\text { reception of material values, timely performance of works, provision of services by } \\
\text { actors, which directly affects the fulfillment of the company's obligations to other } \\
\text { es and its further operation and development }\end{array}$ \\
\hline
\end{tabular}

Source: authors' own development 


\section{МЕНЕДЖМЕНТ}

According to T. L. Mostenska and N. S. Skopenko, risk management is "a set of principles, methods and forms of management of the organization and its behavior in the external environment in conditions of uncertainty and conflict" [2, p. 74]. The authors note that within the framework of risk management three main tasks are solved: risk prevention; minimization of damage caused by risks; maximizing the additional profit that the company receives as a result of risk management. The main purpose of risk management is to reduce or eliminate possible losses from risk, so the definition of principles and functions of risk management are essential for the application of risk management in the enterprise [2].

Risk management is a mandatory element of the social and economic component of the company's product, which allows to generate its social capital through highly effective socio-economic interaction [4, p. 1164].

Thus, the risk management system is identified through its components, including: subjects, purpose, direction, means and methods of effective risk management. Let's consider them below.

First, risk management is a system that unites decision makers and executors, and establishes the order of their interaction (communication). Secondly, it is really management, i.e. the activity in the process of which management decisions are made and implemented. Third, the purpose of the risk management system is to reduce the impact of unforeseen events on the activities of the organization. That is, risk management is not an end in itself, but is auxiliary in relation to the main activities of the organization (activities for which this organization was created). It is only one of the tools that help the organization achieve its goals. Risk management aims to reduce the impact of consequences, not necessarily the consequences themselves. Undoubtedly, the best way of such minimization is to eliminate or maximum reduction of probability and (or) consequences of the risk (the fewer the consequences, the less the impact) [4].

Thus, risk management is an auxiliary set of principles, methods, procedures that eliminate risks or reduce their negative impact on all business processes (purchase, production, sales) and systems (accounting, internal control and audit, planning, investing and financing, management in general).

In order to establish the process of risk management and its minimization in corporations, we consider it is necessary to implement a centralized risk management system. The best organizational form in this case is the creation of a separate structural unit - risk management services. The main purpose of creating a risk management service is to ensure effective risk management and control to achieve current and strategic goals of the company.

The regulatory framework and documentary support for risk management should be developed, based on the provisions of international standards ISO/IEC and best practices in the field of risk management, with the involvement of international consultants and experts [5].

For companies that plan to develop, enter international markets or those that already operate in them, it is important to comply with international standards ISO (International Organization for Standardization) (Fig. 1). ISO international standards are designed to help enterprises, organizations (regardless of type and form of ownership) for implementation and operation of effective risk management systems. The main standard that regulates issues related to risk management is ISO 31000:2018 "Risk management - Guidelines", as well as supporting standards ISO/TR 31004:2013 "Risk management - Guidance for the implementation of ISO 31000" and IEC/ISO 31010:2009 "Risk management - Risk assessment techniques". The last two standards contribute to the effective implementation of ISO 31000 and complement the provisions of the basic standard.

As risks arise in different areas of business management, standards have now been developed to address such issues in different fields. Thus, ISO 45001:2018 "Occupational health and safety management systems - Requirements with guidance for use" and DSTU OHSAS 18001:2010 "Hygiene and labor protection management systems" provide for the implementation of risk-oriented measures for hazard identification, risk assessment and identification of management and control tools. 


\section{МЕНЕДЖМЕНТ}

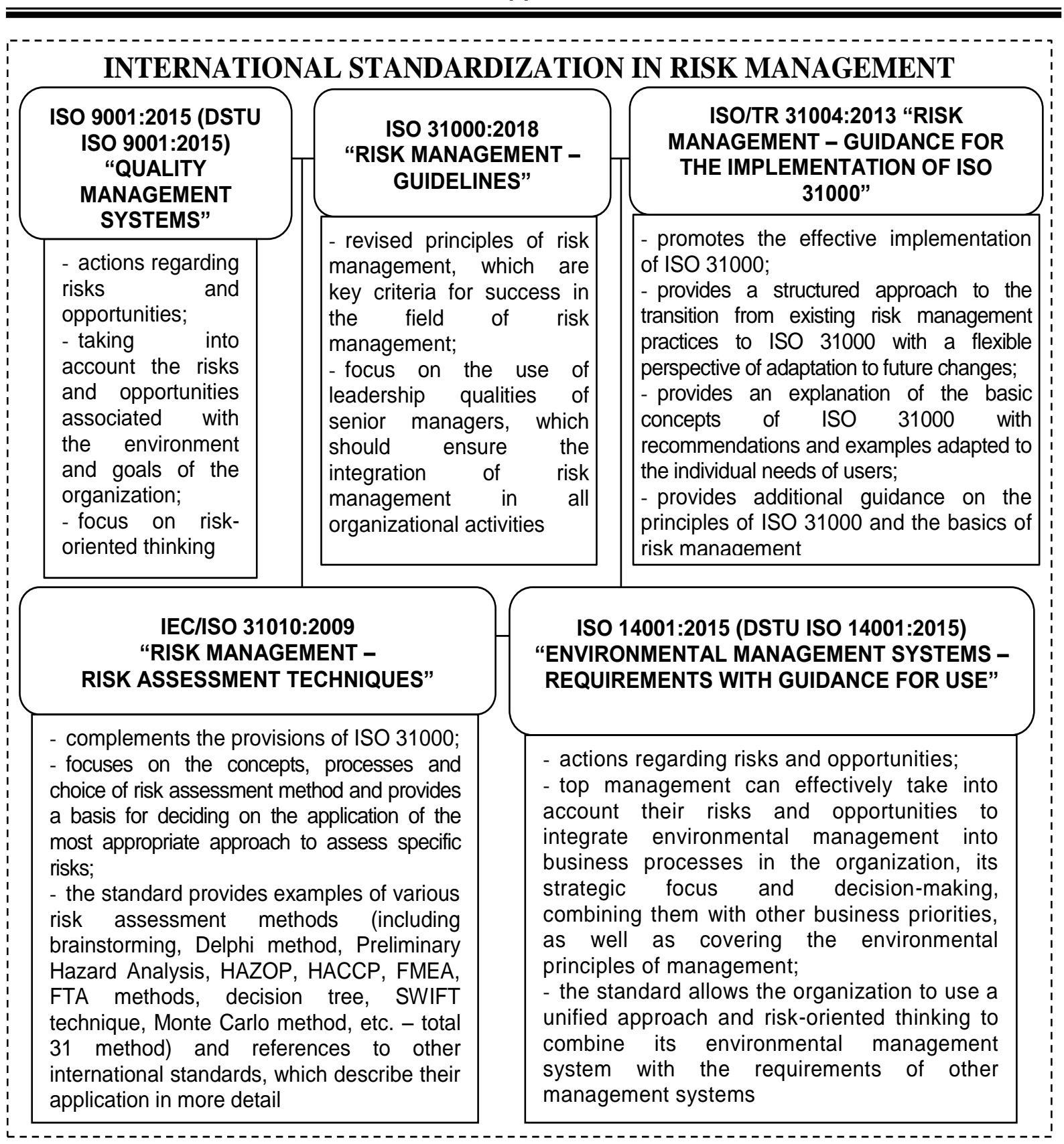

Fig. 1. ISO standards in the risk management system of companies

Source: systematized by the authors on the basis of $[6 ; 7 ; 8 ; 9 ; 10]$

Effective risk management and the implementation of a culture of risk management is achieved by actively involving not only the top management of the company, management staff, but also other groups of employees of various departments of the innovative enterprise. Equally important in risk management is their identification and information support, which is an important aspect for the company's stakeholders. Currently, the most optimal information resource for stakeholder purposes is the management report and integrated reporting, the concept of which provides for the mandatory disclosure of risks of the entity. 


\section{МЕНЕДЖМЕНТ}

Therefore, according to the International Standard "Integrated Reporting" (hereinafter - the concept of IR) accounting system and risk management system through reporting should answer the question: "what specific opportunities and risks affect the company's ability to create value in the short, medium and long term, and how an enterprise uses such opportunities and manages such risks?" [11].

Thus, according to the concept of IR, the main criteria for presenting information about the risks of companies in integrated reporting should include the source of risks and opportunities, risk assessment (probability of occurrence) and its consequences, risk management, i.e. measures, actions (Tab. 2).

It should also be noted that a significant number of corporations in Ukraine compile final annual reports taking into account the Global Reporting Initiative (GRI) [12], which also defines a number of requirements for companies to disclose information about the risks of activities. According to GRI standards, reporting information is presented in the form of a sustainable development report, which is important for building a reputation as an open and trustworthy company.

Table 2

Criteria for presenting information about the company's risks in integrated reporting according to the IR concept

\begin{tabular}{|c|c|c|c|}
\hline № & $\begin{array}{l}\text { Determination } \\
\text { criterion }\end{array}$ & $\begin{array}{l}\text { Characteristics of the risk criterion and its } \\
\text { significance for the stakeholder }\end{array}$ & $\begin{array}{l}\text { Significance criteria for reporting } \\
\text { information about risks }\end{array}$ \\
\hline 1 & 2 & 3 & 4 \\
\hline 1 & $\begin{array}{l}\text { Source of risks } \\
\text { and opportunities }\end{array}$ & $\begin{array}{l}\text { Indicate the specific source of risks and } \\
\text { opportunities, which may be internal (related to } \\
\text { the company's commercial activity), external } \\
\text { (occurring in the external environment) or have } \\
\text { a mixed nature. Coverage of risks of activity in } \\
\text { reporting indicates the openness of the } \\
\text { company and its focus on meeting the needs of } \\
\text { stakeholders, as well as its social responsibility } \\
\text { to society }\end{array}$ & $\begin{array}{l}\text { - explanation of the factor and its impact } \\
\text { on the strategy of the organization, its } \\
\text { business model or capital; } \\
\text { - significant interaction and } \\
\text { interdependence, which allows to } \\
\text { understand the causes and } \\
\text { consequences; } \\
\text { - the company's position to this factor; } \\
\text { - management actions on this factor and }\end{array}$ \\
\hline 2 & $\begin{array}{l}\text { Assessment of risk } \\
\text { (probability of its } \\
\text { occurrence) and } \\
\text { its consequences }\end{array}$ & $\begin{array}{l}\text { An assessment of the probability of the risk or } \\
\text { the possibility and extent of the impact of its } \\
\text { consequences in the event of an occurrence } \\
\text { is declared. Specific circumstances that may } \\
\text { lead to risks or opportunities are indicated. } \\
\text { Assessing the probability of risk allows } \\
\text { stakeholders to correctly place emphasis on } \\
\text { the feasibility of investing and cooperation } \\
\text { with the company, the disposal of their capital }\end{array}$ & $\begin{array}{l}\text { their effectiveness (including the actions } \\
\text { of the risk management system); } \\
\text { - the degree of control of the company } \\
\text { over this factor; } \\
\text { - disclosure of quantitative and } \\
\text { qualitative information, comparative } \\
\text { data for previous periods, targets for } \\
\text { future periods. } \\
\text { If there is uncertainty about any factor, }\end{array}$ \\
\hline 3 & $\begin{array}{l}\text { Risk management } \\
\text { (measures, } \\
\text { actions) }\end{array}$ & $\begin{array}{l}\text { Specific actions are given to reduce and } \\
\text { manage key risks, as well as actions to create } \\
\text { value through the use of key opportunities, } \\
\text { including the definition of relevant strategic } \\
\text { goals, strategies, policies, targets and key } \\
\text { performance indicators. This allows } \\
\text { stakeholders to assess the effectiveness of } \\
\text { the company's management system } \\
\text { (including risk management systems), the } \\
\text { scope and scale of actions and measures, } \\
\text { their economic feasibility }\end{array}$ & $\begin{array}{l}\text { the information about the following } \\
\text { uncertainty shall be disclosed: } \\
\text { - explanation of uncertainty; } \\
\text { - the range of possible outcomes and } \\
\text { related assumptions and possible } \\
\text { changes in information if the } \\
\text { assumptions described do not occur; } \\
\text { - variability, confidence or level of trust } \\
\text { associated with the information provided }\end{array}$ \\
\hline
\end{tabular}

* If it is impossible to determine the most important information about the factor, it is necessary to indicate this and name the reason

Source: systematized on the basis of [11, par. 4.25, par. 4.50], supplemented by the authors

Therefore, let's compare the degree of disclosure of information about the risks of activity (for example, agricultural companies), the assessment of their degree and the risk management measures provided in their annual reports for 2018 (Tab. 3). 


\section{МЕНЕДЖМЕНТ}

Presentation of information on risks, their assessment and risk management in the annual reporting of enterprises of the agro-industrial complex of Ukraine

\begin{tabular}{|c|c|c|c|c|c|c|c|c|}
\hline \multirow[t]{2}{*}{ № } & \multirow[t]{2}{*}{ Risk } & \multirow[t]{2}{*}{ The impact of risk (its consequence) on business } & \multicolumn{3}{|c|}{$\begin{array}{l}\text { Astarta-Kyiv } \\
\text { Agro-Industrial } \\
\text { Holding }\end{array}$} & \multicolumn{3}{|c|}{$\begin{array}{l}\text { PrJSC Carlsberg } \\
\text { Ukraine }\end{array}$} \\
\hline & & & $\mathrm{R}$ & RM & QE & $\mathrm{R}$ & $\mathrm{RM}$ & QE \\
\hline A & B & $\mathbf{C}$ & \multicolumn{3}{|c|}{1} & \multicolumn{3}{|c|}{2} \\
\hline 1 & Country risk & $\begin{array}{l}\text { Political instability has a negative impact on the country's } \\
\text { economic situation, reduces the country's investment } \\
\text { attractiveness, complicates doing business and may have an } \\
\text { unfavorable impact on the company's activities }\end{array}$ & + & + & - & + & + & - \\
\hline 2 & Legal risk & $\begin{array}{l}\text { Lack of legal regulation, changes, unpredictable application } \\
\text { of legal provisions that lead to losses }\end{array}$ & - & - & - & - & - & - \\
\hline 3 & Political risk & $\begin{array}{l}\text { Business may be affected by changes in fiscal, tax and other } \\
\text { restrictive mechanisms }\end{array}$ & + & + & - & + & - & - \\
\hline 4 & Climatic risk & $\begin{array}{l}\text { Unfavorable weather conditions can have a negative impact } \\
\text { on yields and the efficiency of agricultural production }\end{array}$ & + & + & - & - & - & - \\
\hline 5 & Personnel risk & $\begin{array}{l}\text { Lack of qualified staff, failure to ensure normal working } \\
\text { conditions, lack of supervision of staff (performance of their } \\
\text { duties) }\end{array}$ & + & + & - & + & + & - \\
\hline 6 & Production risk & $\begin{array}{l}\text { Deterioration of product quality have a negative impact on } \\
\text { the company's activities, reputation and relations with } \\
\text { customers, decrease in volumes }\end{array}$ & + & + & - & + & - & - \\
\hline 7 & $\begin{array}{l}\text { Logistics risk } \\
\text { (supplies, } \\
\text { purchase) }\end{array}$ & $\begin{array}{l}\text { Impossibility of rhythmic deliveries and deliveries of products } \\
\text { in full - has a negative impact on customer relations and } \\
\text { disrupts the normal functioning of business processes }\end{array}$ & + & + & - & - & - & - \\
\hline 8 & IT risk & $\begin{array}{l}\text { Data loss, data dissemination and breach of the integrity of } \\
\text { IT systems can have a negative impact on the financial } \\
\text { condition and reputation of companies }\end{array}$ & + & + & - & - & - & - \\
\hline 9 & Technical risk & $\begin{array}{l}\text { The use of outdated technologies carries the risk of reduced } \\
\text { productivity }\end{array}$ & + & + & - & - & - & - \\
\hline 10 & $\begin{array}{l}\text { Volatility of } \\
\text { world prices }\end{array}$ & $\begin{array}{l}\text { World price volatility can affect performance and profitability } \\
\text { (price risk) }\end{array}$ & + & + & - & + & + & - \\
\hline 11 & $\begin{array}{l}\text { Changes in gas } \\
\text { and fuel prices }\end{array}$ & $\begin{array}{l}\text { Fluctuations in gas, fuel, and energy prices can affect } \\
\text { performance and profitability }\end{array}$ & + & + & - & & & \\
\hline 12 & Credit risk & $\begin{array}{l}\text { Non-fulfillment of financial obligations by counterparties may } \\
\text { have a negative impact on the company's financial condition }\end{array}$ & + & + & - & + & + & + \\
\hline 13 & Liquidity risk & $\begin{array}{l}\text { The company's inability to meet its financial obligations on } \\
\text { time may negatively affect its financial results }\end{array}$ & + & + & - & + & + & + \\
\hline 14 & $\begin{array}{l}\text { Changes in } \\
\text { interest rates }\end{array}$ & Changes in interest rates can affect financial performance & + & + & - & + & + & \\
\hline 15 & Currency risk & $\begin{array}{l}\text { The devaluation of the Ukrainian hryvnia and exchange rate } \\
\text { fluctuations can negatively affect business }\end{array}$ & + & + & - & + & + & + \\
\hline 16 & $\begin{array}{l}\text { Environmental } \\
\text { risk }\end{array}$ & $\begin{array}{l}\text { Probability of adverse effects of changes in natural objects } \\
\text { (resources) and factors of activity on the environment and } \\
\text { health }\end{array}$ & - & - & - & + & + & - \\
\hline 17 & Social risk & $\begin{array}{l}\text { Human-type events regarding the danger of loss of material } \\
\text { resources to meet the priority needs necessary to preserve } \\
\text { and reproduce a full life as a member of human society }\end{array}$ & - & - & - & + & + & - \\
\hline 18 & $\begin{array}{l}\text { The risk of } \\
\text { business } \\
\text { expansion } \\
\text { failure }\end{array}$ & $\begin{array}{l}\text { Losses caused by failures of geographical development of } \\
\text { the company, acquisition of new productions, integration of } \\
\text { new enterprises }\end{array}$ & - & - & - & - & - & - \\
\hline 19 & Investment risk & Inefficiency of real/financial investments, losses & - & - & - & - & - & - \\
\hline 20 & $\begin{array}{l}\text { Public risk } \\
\text { (municipal) }\end{array}$ & $\begin{array}{l}\text { Negative impact on human rights, community, stakeholders, } \\
\text { which has negative reputational consequences }\end{array}$ & - & - & - & - & - & - \\
\hline 21 & $\begin{array}{ll}\text { Risk } & \text { of } \\
\text { corruption }\end{array}$ & Offenses related to corrupt practices & - & - & - & - & - & - \\
\hline Total & & & 14 & 14 & 0 & 11 & 9 & 3 \\
\hline
\end{tabular}




\section{МЕНЕДЖМЕНТ}

\begin{tabular}{|c|c|c|c|c|c|c|c|c|c|c|c|c|c|c|c|c|}
\hline & & & & & & & & & & & & \multicolumn{5}{|c|}{ Continuation of Table 3} \\
\hline \multirow[t]{2}{*}{ № } & \multirow[t]{2}{*}{ Risk } & \multicolumn{3}{|c|}{$\begin{array}{l}\text { Agro-Industrial } \\
\text { Holding } \\
\text { Mironivsky } \\
\text { Hliboproduct } \\
\end{array}$} & \multicolumn{3}{|c|}{$\begin{array}{c}\text { PrJSC } \\
\text { Vetropack } \\
\text { Gostomel } \\
\text { Glass Factory }\end{array}$} & \multicolumn{3}{|c|}{ PJSC Obolon } & \multicolumn{3}{|c|}{$\begin{array}{c}\text { PrJSC Kyiv } \\
\text { Confectionery } \\
\text { Factory "Roshen" }\end{array}$} & \multicolumn{3}{|c|}{$\begin{array}{c}\text { The Coca-Cola } \\
\text { System }\end{array}$} \\
\hline & & $\mathrm{R}$ & RM & $\mathrm{QE}$ & $\mathrm{R}$ & $\mathrm{RM}$ & QE & $\mathrm{R}$ & RM & $\mathrm{QE}$ & $\mathrm{R}$ & $\mathrm{RM}$ & QE & $\mathrm{R}$ & RM & QE \\
\hline $\mathbf{A}$ & B & \multicolumn{3}{|c|}{3} & \multicolumn{3}{|c|}{4} & \multicolumn{3}{|c|}{5} & \multicolumn{3}{|c|}{6} & \multicolumn{3}{|c|}{7} \\
\hline 1 & Country risk & - & - & - & + & + & - & + & - & - & - & - & - & - & - & - \\
\hline 2 & Legal risk & + & + & - & + & + & - & + & - & - & - & - & - & - & - & - \\
\hline 3 & Political risk & - & - & - & + & + & - & + & - & - & - & - & - & - & - & - \\
\hline 4 & Climatic risk & + & + & - & - & - & - & - & - & - & - & - & - & - & - & - \\
\hline 5 & Personnel risk & + & + & - & + & + & - & - & - & - & - & - & - & + & + & - \\
\hline 6 & Production risk & + & + & - & + & + & - & + & - & - & - & - & - & + & + & - \\
\hline 7 & $\begin{array}{ll}\text { Logistics risk } \\
\text { (supplies, } \\
\text { purchase) }\end{array}$ & + & + & - & - & - & - & - & - & - & - & - & - & + & + & - \\
\hline 8 & IT risk & + & + & - & - & - & - & - & - & - & - & - & - & - & - & - \\
\hline 9 & Technical risk & + & + & - & - & - & - & - & - & - & - & - & - & - & - & - \\
\hline 10 & $\begin{array}{l}\text { Volatility of } \\
\text { world prices }\end{array}$ & + & + & - & - & - & - & + & - & - & - & - & - & - & - & - \\
\hline 11 & $\begin{array}{l}\text { Changes in } \\
\text { gas and fuel } \\
\text { prices }\end{array}$ & + & + & - & - & - & - & + & - & - & - & - & - & - & - & - \\
\hline 12 & Credit risk & + & + & - & + & + & - & + & + & + & + & + & & - & - & - \\
\hline 13 & Liquidity risk & + & + & - & + & + & - & + & + & + & + & + & & - & - & - \\
\hline 14 & $\begin{array}{l}\text { Changes in } \\
\text { interest rates }\end{array}$ & - & - & - & - & - & - & + & + & + & + & - & & - & - & - \\
\hline 15 & Currency risk & - & - & - & + & + & - & + & + & + & + & - & & - & - & - \\
\hline 16 & $\begin{array}{l}\text { Environmental } \\
\text { risk }\end{array}$ & + & + & - & - & - & - & - & - & - & - & - & - & + & + & - \\
\hline 17 & Social risk & - & - & - & - & - & - & - & - & - & - & - & - & + & + & - \\
\hline 18 & $\begin{array}{l}\text { The risk of } \\
\text { business } \\
\text { expansion } \\
\text { failure }\end{array}$ & + & + & - & - & - & - & - & - & - & - & - & - & - & - & - \\
\hline 19 & Investment risk & + & + & - & - & - & - & - & - & - & - & - & - & - & - & - \\
\hline 20 & $\begin{array}{l}\text { Public risk } \\
\text { (municipal) }\end{array}$ & + & + & - & - & - & - & - & - & - & - & - & - & - & - & - \\
\hline 21 & $\begin{array}{ll}\text { Risk } & \text { of } \\
\text { corruption }\end{array}$ & + & + & - & - & - & - & - & - & - & - & - & - & + & + & - \\
\hline Tota & & 16 & 16 & 0 & 8 & 8 & 0 & 10 & 4 & 4 & 4 & 2 & 0 & 6 & 6 & 0 \\
\hline
\end{tabular}

\begin{tabular}{|c|c|c|c|c|c|c|c|c|c|c|c|c|c|c|}
\hline \multirow{3}{*}{ № } & \multirow{3}{*}{ Risk } & \multirow{2}{*}{\multicolumn{3}{|c|}{$\begin{array}{l}\text { PJSC Lebedyn Seed } \\
\text { Plant }\end{array}$}} & \multirow{2}{*}{\multicolumn{3}{|c|}{$\begin{array}{l}\text { Goodvalley } \\
\text { CSR }\end{array}$}} & & & & & on & $T a b$ & \\
\hline & & & & & & & & \multicolumn{3}{|c|}{$\begin{array}{c}\text { PrJSC } \\
\text { Lantmannen } \\
\text { Axa }\end{array}$} & \multicolumn{3}{|c|}{$\begin{array}{l}\text { The group of } \\
\text { companies ATK }\end{array}$} & \multirow{2}{*}{ 要 } \\
\hline & & $\mathrm{R}$ & $\mathrm{RM}$ & QE & $\mathrm{R}$ & $\mathrm{RM}$ & $\mathrm{QE}$ & $\mathrm{R}$ & $\mathrm{RM}$ & $\begin{array}{l}\mathrm{Q} \\
\mathrm{E}\end{array}$ & $\mathrm{R}$ & $\mathrm{RM}$ & QE & \\
\hline A & B & \multicolumn{3}{|c|}{8} & \multicolumn{3}{|c|}{9} & \multicolumn{3}{|c|}{10} & \multicolumn{3}{|c|}{11} & D \\
\hline 1 & Country risk & - & - & - & + & + & - & - & - & - & - & - & - & 5 \\
\hline 2 & Legal risk & - & - & - & - & - & & - & - & - & + & + & - & 4 \\
\hline 3 & Political risk & - & - & - & + & + & - & - & - & - & - & - & - & 5 \\
\hline 4 & Climatic risk & - & - & - & - & - & & - & - & - & + & + & - & 3 \\
\hline 5 & Personnel risk & - & - & - & + & + & & - & - & - & + & + & - & 7 \\
\hline 6 & Production risk & - & - & - & + & + & - & - & - & - & - & - & - & 7 \\
\hline 7 & $\begin{array}{l}\text { Logistics risk } \\
\text { purchase) }\end{array}$ & - & - & - & - & - & - & - & - & - & + & + & - & 4 \\
\hline 8 & IT risk & - & - & - & + & + & - & - & - & - & - & - & - & 3 \\
\hline 9 & Technical risk & - & - & - & - & - & - & - & - & - & - & - & - & 2 \\
\hline 10 & Volatility of world prices & + & - & - & + & + & - & - & - & - & + & + & - & 7 \\
\hline
\end{tabular}




\section{МЕНЕДЖМЕНТ}

\begin{tabular}{|c|c|c|c|c|c|c|c|c|c|c|c|c|c|c|}
\hline & & & & & & & & & \multicolumn{6}{|c|}{ Continuation of Table 3} \\
\hline A & $\mathbf{B}$ & \multicolumn{3}{|c|}{8} & \multicolumn{3}{|c|}{9} & \multicolumn{3}{|c|}{10} & \multicolumn{3}{|c|}{11} & D \\
\hline 11 & $\begin{array}{l}\text { Changes in gas and fuel } \\
\text { prices }\end{array}$ & + & - & - & - & - & - & - & - & - & - & - & - & 4 \\
\hline 12 & Credit risk & + & - & - & - & - & - & + & + & - & + & + & - & 9 \\
\hline 13 & Liquidity risk & - & - & - & - & - & - & + & + & - & + & 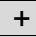 & - & 8 \\
\hline 14 & Changes in interest rates & - & - & - & - & - & - & + & + & - & + & + & - & 6 \\
\hline 15 & Currency risk & - & - & - & + & + & - & - & - & - & - & - & - & 6 \\
\hline 16 & Environmental risk & - & - & - & + & + & - & - & - & - & - & - & - & 4 \\
\hline 17 & Social risk & - & - & - & - & - & - & - & - & - & - & - & - & 2 \\
\hline 18 & $\begin{array}{l}\text { The risk of business } \\
\text { expansion failure }\end{array}$ & - & - & - & - & - & - & - & - & - & - & - & - & 1 \\
\hline 19 & Investment risk & - & - & - & - & - & - & - & - & - & - & - & - & 1 \\
\hline 20 & Public risk (municipal) & - & - & - & - & - & - & - & - & - & + & + & - & 2 \\
\hline 21 & Risk of corruption & - & - & - & + & + & - & - & - & - & - & - & - & 3 \\
\hline Tot & & 3 & 0 & 0 & 9 & 9 & 0 & 3 & 3 & 0 & 8 & 8 & 0 & $\mathrm{X}$ \\
\hline
\end{tabular}

Notes: R - risk; RM - risk management; QE - quantitative expression (measurement, evaluation)

Source: developed by the authors according to $[13 ; 14 ; 15 ; 16 ; 17 ; 18 ; 19 ; 20 ; 21 ; 22 ; 23 ; 24]$

It should be noted that for the analysis has been used the reports of companies prepared according to both IR and GRI standards, as well as management reports (according to the Law of Ukraine "On Accounting and Financial Reporting in Ukraine") and annual reports of issuers of securities (according to the Provision of NSSMC on disclosure of information by issuers of securities). This is due to the fact that information on risks is partly of a financial nature and is disclosed in non-financial statements of enterprises.

The analysis revealed that the issues of business risks, their consequences, risk management and capabilities of domestic agricultural enterprises are disclosed in the most complete and transparent way in the reports on sustainable development of Agro-Industrial Holding Mironivsky Hliboproduct, Astarta-Kyiv Agro-Industrial Holding, PrJSC Carlsberg Ukraine and in the report on the management of PJSC Obolon (Table 3).

The study showed that socially responsible companies in their activities are most affected by: 1) credit risk - 9 companies out of 11 surveyed; 2 ) liquidity risk $-8 ; 3$ ) the risk of volatility of world prices, production risk and personnel risk $-7 ; 4$ ) the risk of changes in interest rates and currency risk $-6 ; 5$ ) political risk and country risk - 5 companies. Other risks are specific, have a low frequency of information about them in the reports, particular only to individual companies, which may indicate their dependence on the specifics of the business, its geographical location etc.

Nowadays, as always, the issue of quantitative measurement of the degree of risk and value assessment of its consequences and opportunities is critical. The analysis of companies' annual reports has been showed that those responsible for compiling these reports continue to ignore this issue. Only two of the eleven surveyed companies (PrJSC Carlsberg Ukraine and PJSC Obolon) provided quantitative values for several risks of their activities; the validity of the choice of these risks for the quantitative analysis of the enterprise is not given.

Conclusions. Thus, the identified problem of disclosing information in the reports of socially responsible companies about significant risks, their consequences and opportunities, their quantitative measurement (assessment) and impact factors is due to the inability of the enterprise information system (including integrated) to provide the necessary information. Also the reason for this is an improper organized management system in general and/or risk management system in particular. Regarding socially-oriented business risks, it has been concluded that only a small number of surveyed companies noted such information in their reports (public, social, personnel, environmental risks, corruption risk, etc.) and this indicates a low/insufficient level of corporate social responsibility of certain enterprises.

Prospects for further research are to solve the problem of integration of all systems of company to create the most effective integrated information system of the business entity, which will provide a high level of business management and satisfy the interests of stakeholders. 


\section{МЕНЕДЖМЕНТ}

\begin{abstract}
References
1. Lytjuga Ju. V. (2012). Orhanizatsiia ryzykmenedzhmentu na pidpryiemstvi [Organization of risk management at the enterprise]. Ekonomika pidpryjemstva: teorija i praktyka - Business Economics: Theory and Practice : 4th International Scientific and Practical Conference. Retrieved from http://kneu.edu.ua/ua/departments/Faculty_of_Economics_a nd_Administration/confere_nce/ec_pidpr_th_pr_4/sect5/ [in Ukrainian].

2. Vyhivska I. M., Hryhorevska O. O., Lyakhovich G. I., Khomenko, H. Y. (2019). Organization of accounting and risk-management of educational activity: development directions in the conditions of implementation of the quality management system. Financial and credit activities: problems of theory and practice, 4(31), 82-93. Retrieved from http://fkd.org.ua/article/view/190801 [in English].

3. Mostenska T. L., Skopenko N. S. (2010). Ryzykmenedzhment yak instrument upravlinnia hospodarskym ryzykom pidpryiemstva [Risk management as a tool for managing an enterprise's economic risk]. Visnyk Zaporizkoho natsionalnoho universytetu. Ekonomichni nauky - Visnyk of Zaporizhzhya National University. Economic sciences, 3(7), 72-79 [in Ukrainian].

4. levdokymov V., Lehenchuk S., Zakharov D., Andrusiv U., Usatenko O., Kovalenko L. (2020). Social capital measurement based on "The value explorer" method. Management Science Letters, 10(6), 1161-1168. Retrieved from http://growingscience.com/beta/msl/3580-social-capitalmeasurement-based-on-the-value-explorer-method.html
\end{abstract} [in English].

5. Upravlinnia ryzykamy [Risk management]. (n.d.) www.naftogaz.com. Retrieved from http://www.naftogaz. com/www/3/nakweb.nsf/0/E9234D35DD4DC719C2257F1F0 04B2D86?OpenDocument\&Expand=5\& [in Ukrainian].

6. Systemy ekolohichnoho upravlinnia. Vymohy ta nastanovy schodo zastosovuvannia [Environmental Management Systems. Application requirements and guidelines]. (2016). DSTU ISO 14001:2015, IDT. Retrieved from http://online.budstandart.com/ua/catalog/docpage?id_doc $=64015$ [in Ukrainian].

7. Systemy ekologichnogo upravlinnja. Vymogy ta nastanovy shhodo zastosovuvannja [Systemy ekologichnogo upravlinnja. Vymogy ta nastanovy shhodo zastosovuvannja] (2016). DSTU ISO 14001:2015. Retrieved from http://online.budstandart.com/ua/catalog/docpage?id_doc $=6$ 4015 [in Ukrainian].

8. Systemy ekologichnogo upravlinnja. Vymogy ta nastanovy shhodo zastosovuvannja [Environmental management systems. Application requirements and guidelines]. (2016). DSTU ISO 14001:2015. Retrieved from http://online.budstandart.com/ua/catalog/docpage?id_doc=6 4015 [in Ukrainian].

9. Mizhnarodna standartyzacija: Opublikovana nova versija standartu ISO 31000 na upravlinnja ryzykamy [International Standardization: A new version of ISO 31000 to risk management has been published]. (2018). sm.kiev.ua. Retrieved from http://csm.kiev.ua/index php?option=com_content $\&$ view $=$ article $\&$ id $=4112 \% 3 \mathrm{~A}$-iso31000\& catid=122\%3A2015-09-15-07-01-23\&lang=uk [in Ukrainian].

10. Seriia standartov ISO 31000. Menedzhment riskov [Series of standards ISO 31000. Risk management]. (n.d.) intercert.com.ua. Retrieved from https://intercert.com.ua/ articles/regulatory-documents/311-iso-31000-riskmanagement [in Russian].

\section{1. Литюга Література} підприємстві / Ю. В. Литюга // Економіка підприємства: теорія і практика: IV Міжнародна науково-практична конференція, КНЕУ ім. В. Гетьмана, 2012 [Електронний ресурс]. http://kneu.edu.ua/ua/departments/Faculty_of_Economics_and _Administration/confere_nce/ec_pidpr_th_pr_4/sect5/.

2. Vyhivska, I. M. Organization of accounting and riskmanagement of educational activity: development directions in the conditions of implementation of the quality management system / I. M. Vyhivska, O. O. Hryhorevska, G. I. Lyakhovich, H. Y. Khomenko // Financial and credit activities: problems of theory and practice. - № 4 (31). - 2019 - P. 82-93 Retrieved from http://fkd.org.ua/article/ view/190801.

3. Мостенська Т. Л. Ризик-менеджмент як інструмент управління господарським ризиком підприємства / Т. Л. Мостенська, Н. С. Скопенко // Вісник Запорізького національного університету. Економічні науки. - 2010. - № 3 (7). - C. 72-79.

4. levdokymov V. Social capital measurement based on "The value explorer" method / V. levdokymov, S. Lehenchuk, D. Zakharov, U. Andrusiv, O. Usatenko, L. Kovalenko // Management Science Letters. - 2020. - Volume 10, Issue 6. - 6 P. 1161-1168 Retrieved from http://growingscience.com/beta/msl/3580-social-capitalmeasurement-based-on-the-value-explorer-method.html.

5. Нафтогаз група. Управління ризиками Електронний pecypc. - Режим доступу: http://www.naftogaz.com /www/3/nakweb.nsf/0/E9234D35DD4DC719C2257F1F004B2 D86?OpenDocument\&Expand $=5 \&$.

6. ДСТУ ISO 14001:2015 Системи екологічного управління. Вимоги та настанови щодо застосовування (ISO 14001:2015, IDT) Електронний ресурс. - Режим доступу: $\quad$ http://online.budstandart.com/ua/catalog/docpage?id_doc $=64015$

7. ДСТУ ISO 14001:2015 Системи екологічного управління. Вимоги та настанови щодо застосовування (ISO 14001:2015, IDT) Електронний ресурс. - Режим доступу: http://online.budstandart.com/ua/catalog/docpage?id_doc $=64015$

8. ДСТУ ISO 14001:2015 Системи екологічного управління. Вимоги та настанови щодо застосовування (ISO 14001:2015, IDT) Електронний ресурс. - Режим доступу: $\quad$ http://online.budstandart.com/ua/catalog/docpage?id_doc $=64015$.

9. Міжнародна стандартизація: Опублікована нова версія стандарту ISO 31000 на управління ризиками Електронний ресурс. - Режим доступу: http://csm.kiev. ua/index.php?option $=$ com content $\&$ view $=$ article \& id $=4112 \% 3 \mathrm{~A}$ -iso-31000-\&catid=122\%3A2015-09-15-07-01-23\&lang=uk.

10. Серия стандартов ISO 31000. Менеджмент рисков Електронний ресурс. - Режим доступу: https://intercert.com.ua/articles/regulatory-documents/311-iso31000-risk-management.

11. Международный стандарт «Интегрированная отчётность». IR Електронний ресурс $\square$. - Режим доступу: https://integratedreporting.org/wp-content/uploads/2015/ 03/13-12-08-THE-INTERNATIONAL-IR-

FRAMEWORK.docx_en-US_ru-RU.pdf

12. Стандарти GRI: звітність у зрозумілому для інвесторів вигляді Електронний ресурс. - Режим доступу: http://msfz.ligazakon.ua/ua/magazine_article/FZ001041/.

13. Звіт зі сталого розвитку 2018. АСТАРТА-КИїв Агропромхолдинг Електронний ресурс. - Режим доступу: 


\section{МЕНЕДЖМЕНТ}

11. Mezhdunarodnyy standart «Integrirovannaya otchetnost». IR [International standard "Integrated reporting" IR]. (2013). integratedreporting.org. Retrieved from https://integratedreporting.org/wpcontent/uploads/2015/03/13-12-08-THE-INTERNATIONALIR-FRAMEWORK.docx_en-US_ru-RU.pdf [in Russian].

12. Standarty GRI: zvitnist u zrozumilomu dlia investoriv vyhliadi [GRI Standards: Investor-friendly reporting]. (n.d.). msfz.ligazakon.ua. Retrieved from https://msfz.ligazakon.ua/ ua/magazine article/FZ001041 [in Ukrainian].

13. Zvit zi stalogo rozvytku 2018. ASTARTA-KYIV Agropromholdyng [Sustainable Development Report 2018. ASTARTA-KYIV Agropromholding]. (2018). astartaholding.com. Retrieved from https://astartaholding. com/files/uploads/2539e1b1ae6dc6666f11f65aeeba5dc7.pdf [in Ukrainian].

14. Zvit zi staloho rozvytku 2018. PrAT «KARLSBERG Ukraina» [Sustainable Development Report 2018. JSC CARLSBERG Ukraine]. (2018). carlsbergukraine.com. Retrieved from https://carlsbergukraine.com/media/ 33840/report-2018.pdf [in Ukrainian].

15. Annual report and accounts 2018. A leading international agro-industrial company. Agro and industrial holding MHP. (2018). www.mhp.com.ua. Retrieved from https://www.mhp.com.ua/library/file/mhp-ar-2018-finaledited.pdf [in English].

16. Zvit pro upravlinnia 2018. PrAT «Vetropak Gostomelskyi sklozavod» [Management Report 2018. Vetropack Gostomel Glass Works JSC]. (2018). www.vetropack.ua. Retrieved from https://www.vetropack. ua/fileadmin/ua/doc/Richna_informacija_Emitenta_za_2018_ rik.pdf [in Ukrainian].

17. Sustainability Report 2018. Vetropack Group. (2018). www.vetropack.ua. Retrieved from https://www.vetropack. ua/fileadmin/img/03_Sustainability/04_sustainability_reports/ Sustainability_Report_2018.pdf [in English].

18. Zvit pro upravlinnia. Richna informatsiia emitenta tsinnyh paperiv (richnyi zvit) za 2018 rik. PAT «Obolon» [Management Report. Securities Issuer Annual Information (Annual Report) for 2018. Obolon PJSC]. (2018). obolon.ua. Retrieved from http://obolon.ua/ua/about/shareholders [in Ukrainian].

19. Richna informacija emitenta cinnyh paperiv za 2018 rik. PrAT «Kyi'vs'ka kondyters'ka fabryka «Roshen» [Securities Issuer Annual Information for 2018. PJSC «Kyiv Confectionery Factory« Roshen»]. (2018). kcf.roshen.com. Retrieved from http://kcf.roshen.com/ [in Ukrainian].

20. Zvit zi staloho rozvytku systemy kompanii Koka-Kola v Ukraini za 2018 rik [Sustainability Report on Coca-Cola Companies in Ukraine for 2018]. (2018). www.coca-cola.ua. Retrieved from https://www.coca-cola.ua/content /dam/one/ua/uk/pdf-files/coca-cola-corporate-report-gri2018.pdf [in Ukrainian].

21. Richna zvitnist emitenta tsinnyh paperiv (richnyi zvit) za 2018 r. PAT «Lebedynskyi nasinnievyi zavod» [Securities Issuer Annual Report (Annual Report) for 2018 PJSC "Lebedinsky Seed Plant"]. (2018). www.Inz.com.ua. Retrieved from https://www.Inz.com.ua/group/informatsiiapro-pidpriiemstvo [in Ukrainian].

22. Annual report 2018. Goodvalley CSR. (2018). www.goodvalley.com. Retrieved from https://www. goodvalley.com/media/1478/goodvalley-annual-report2018.pdf [in English].

23. Zvit pro upravlinnia PrAT «Lantmannen Aksa» za 2018 rik [Management Report of Lantmannen Aksa PJSC for 2018]. (2018). lantmannen.ua. Retrieved from https://astartaholding.com/files/uploads/2539e1b1ae6dc6666f1 1f65aeeba5dc7.pdf.

14. Звіт зі сталого розвитку 2018. ПрАТ «КАРЛСБЕРГ Україна» Електронний ресурс. - Режим доступу: https://carlsbergukraine.com/media/33840/report-2018.pdf.

15. Annual report and accounts 2018. A leading international agro-industrial company. Agro and industrial holding MHP $\square$ Електронний ресурс. - Режим доступу: https://www.mhp.com.ua/library/file/mhp-ar-2018-finaledited.pdf.

16. Звіт про управління 2018. ПрАТ «Ветропак Гостомельський склозавод» Електронний ресурс. - Режим доступу: https://www.vetropack.ua/fileadmin/ ua/doc/Richna_informacija_Emitenta_za_2018_rik.pdf.

17. Sustainability Report 2018. Vetropack Group Електронний ресурс. - Режим доступу: https://www.vetropack.ua/fileadmin/img/03_Sustainability/04_s ustainability_reports/Sustainability_Report_2018.pdf.

18. Звіт про управління. Річна інформація емітента цінних паперів (річний звіт) за 2018 рік. ПАТ «Оболонь» Електронний ресурс. - Режим доступу: http://obolon.ua/ua/about/shareholders.

19. Річна інформація емітента цінних паперів за 2018 рік. ПрАТ «Київська кондитерська фабрика «Рошен» Електронний ресурс. - Режим доступу: http://kcf.roshen.com/.

20. Звіт зі сталого розвитку системи компаній КокаКола в Україні за 2018 рік Електронний ресурс. - Режим доступу: https://www.coca-cola.ua/content/dam/ one/ua/uk/pdf-files/coca-cola-corporate-report-gri-2018.pdf.

21. Річна звітність емітента цінних паперів (річний звіт) за 2018 р. ПАТ «Лебединський насіннєвий завод» Електронний ресурс. - Режим доступу: https://www.Inz.com.ua/group/informatsiia-pro-pidpriiemstvo.

22. Annual report 2018. Goodvalley CSR घЕлектронний pecypc. - Режим доступу: https://www.goodvalley. com/media/1478/goodvalley-annual-report-2018.pdf.

23. Звіт про управління ПрАТ «Лантманнен Акса» за 2018 рік. Електронний ресурс - Режим доступу: http://lantmannen.ua/sites/default/files/zvit_2018.pdf.

24. Річний звіт. Звіт про управління та фінансова звітність. 2018. Частина 2. Група компаній АТК Електронний ресурс. - Режим доступу: http://atk.com.ua/ua/get_file/id/26pdfsamatk-zvit-proupravlinnja-chastina-2.pdf. 


\section{МЕНЕДЖМЕНТ}

http://lantmannen.ua/sites/default/files/zvit_2018.pdf

[in Ukrainian].

24. Richnyi zvit. Zvit pro upravlinnia ta finansova zvitnist. 2018. Chastyna 2. Grupa kompanii ATK [Annual report. Management Report and Financial Reporting. 2018. Part 2. ATK Group of Companies]. (2018). atk.com.ua. Retrieved from http://atk.com.ua/ua/get_file/id/26pdfsamatk-zvit-proupravlinnja-chastina-2.pdf [in Ukrainian].

Received for publicatio 28.04 .2020

\section{Бібліографрічний опис для цитування:}

Lehenchuk S. F., Vygivska I. M., Barchak T. P. Information support issues of risk management of socially responsible corporations. Науковий вісник Полісся. 2020. № 1 (20)., С. 92-103.

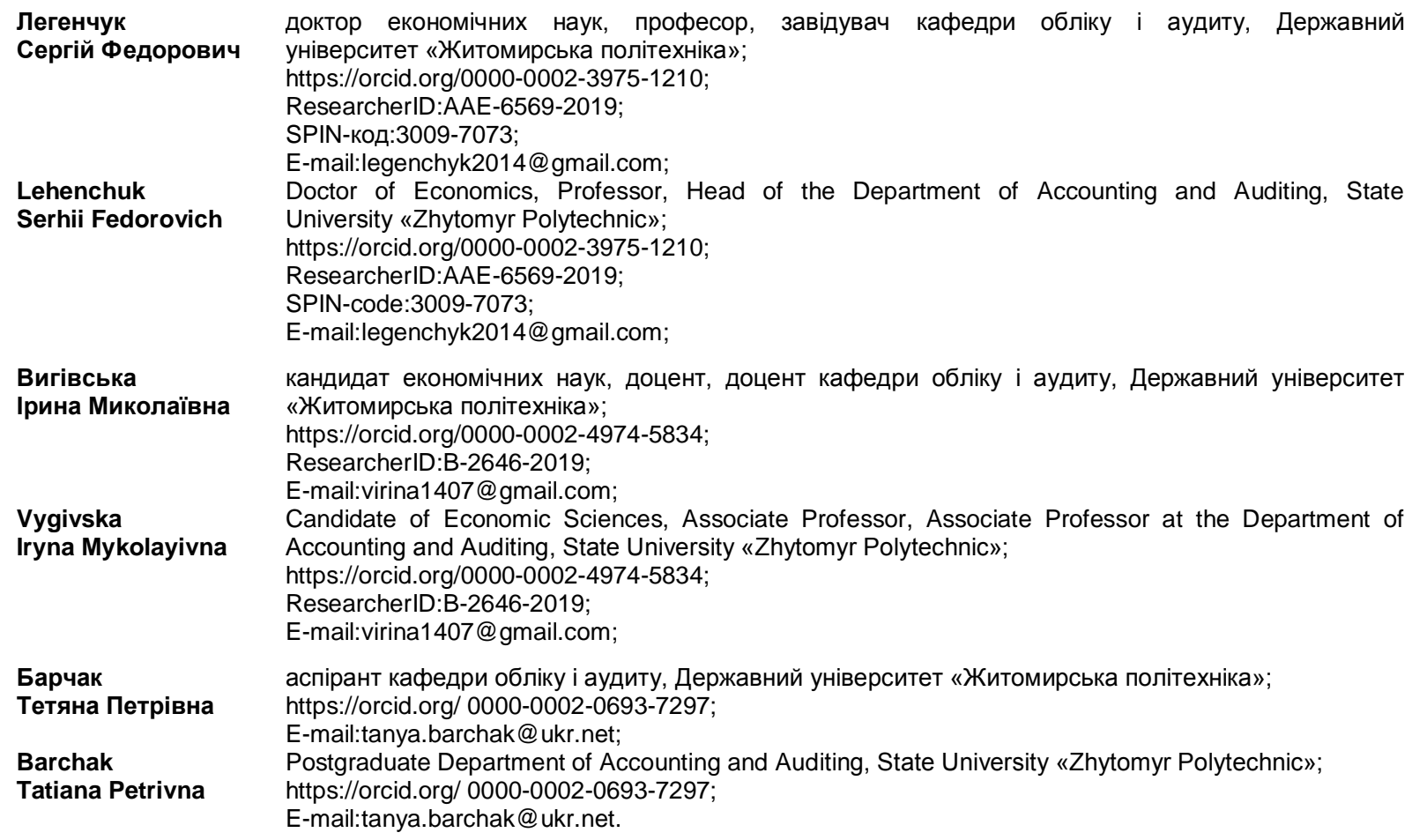

